\title{
The construction of self and others: A study of the identity construction in I am Malala
}

\author{
Asifa Qasim*1 ${ }^{1}$ Sage Lambert Graham ${ }^{2}$
}

1. Department of English Language and Translation Studies, College of Arabic and Social Studies, Qassim University, Saudi Arabia.

2. Department of English, The University of Memphis, Tennessee, United States.

*Corresponding Author Emails: asifaqasim@gmail.com | a.awan@qu.edu.sa

\begin{abstract}
Autobiographical memoirs incorporate personal experiences of an individual and the cultural structures for recognizing lives and identities. They mediate between actions and point of view of an author to display the identity of self and others. The language of autobiographical narratives situates characters in relation to one another to distinguish between self and other. This study examines the approach adopted by Malala for her identity construction in her autobiography, explicating the ways she maintains or challenges the social customs through these ideologies. It analyses linguistic features employed by Malala for identity construction and ideological distinctions between the victims and the perpetrators, stigmatized and non-stigmatized in her story. Malala appears in her tales as an author with authority, as well as a victim of intolerance and abuse, according to the findings; however, her identity is often fluid and changing through acquiring the roles of victim, figure, and author, and depicting her characters in parallel roles. She positioned characters in her story by making overt and covert contrasts within reported events. Her narrative shows a contentious case of discrimination in which both the victim and the perpetrator are Pashtun Muslims from Pakistan of the same race, religion, and ethnicity.

Article History

Received:

March 7, 2021

Last Revised:

June 11,2021

Accepted:

June 26, 2021

Published:

June 30, 2021
\end{abstract}

Keywords: Malala, autobiography, gender, identity, Pashtun identity, Pashtun culture, positioning, victim, perpetrator, stigmatized, non-stigmatized, militancy.

How to Cite: Qasim, A. \& Graham, S. L. (2021). The construction of self and others: A study of the identity construction in I am Malala. Liberal Arts and Social Sciences International Journal (LASSIJ), 5(1), 597-610. https://doi.org/10.47264/idea.lassij/5.1.39

Publisher's Note: IDEA PUBLISHERS (IDEA Journals Group) stands neutral with regard to the jurisdictional claims in the published maps and the institutional affiliations.

Copyright: () 2021 The Author(s), published by IDEA PUBLISHERS (IDEA Journals Group). This is an Open Access article published under the Creative Commons Attribution-NonCommercial 4.0 International License (http://creativecommons.org/licenses/by-nc/4.0/) 


\section{Introduction}

Malala Yousafzai survived Taliban's shooting in her head at the age of 16 years in 2012 for her activism in girls' education in Pakistan. At an age of 11 years in early 2009, Malala started writing a BBC blog about life under the Talibanization (January-March 2009). Once her identity was discovered by the Taliban, she got shot in her head when she was riding her school bus back to her house in October 2012. The attempted assassination sparked a national and international outpouring of sympathy for Malala. In January 2013, Deitsche Welle commented that Yousaf Zai may perhaps have turned out to be "the most famous teenager in the world." She was the first to win National Youth Peace Prize of Pakistan and was awarded Nobel Peace Prize in 2014.

On October 16, 2013, the Policy mic newspaper compiled a collection of Tweets saying, Why Do Malala Conspiracy Theories Go Viral? The response revealed that Malala's rising to fame was far less celebrated in Pakistanis in comparison to the West. Pakistanis considered it patently deceitful that Malala was being revered while there was a disregard for numerous others in parallel circumstances. She enjoyed a strong position since BBC specially chose her by providing her a voice in international media and thus ensured that her life was saved (ZahraMalik 2013; Baig, 2013). Aziz and Buncombe (2013) described her as being employed as a puppet to rationalize Western imperialism focused on saving the natives.

Malala's autobiographical narrative, I am Malala (2013) opens with her father's remarkably progressive approach towards girls' education. This stance leads Malala to build up a strong passion for knowledge, egalitarianism, and integrity at a tender age in the story. Malala is fiery and intelligent and dreams of bringing change in the world, however, this report has the added benefit of being a factual story that can easily be linked to key worldwide issues such as education, human rights, peace, and development. The message of Malala is no doubt very important and pertinent: that every individual has the right for getting education. Nonetheless, in the background of this plain and touching account is the more intricate relationship between the West and Asia, underlined by the incomparable nature of the rise of Malala to prominence at national and international level (Ashish \& Narain, 2015). Her interviews on TV were so direct and powerful, even being honest and confrontational, that it could be sensed as if Malala were on purpose being pressed to talk to incite the Taliban (Arnoldy, 2012; Siddiqui, 2013; Waraich, 2013).

Considering the reviews by Pakistani writers on Malala's book and commentary of social media users on her way of stating out her opinion about her country and making every possible effort for availability of education for all, the study analyzes the means devised by her in construction of the identities of different characters involved in her story through linguistic features in particular to portray the self and others by identifying with or distancing from other people in her account.

Through the use of distinct language elements, this study tries to contribute to the studies of race and identity particularly in Pakistan, by evaluating the autobiography, with a special focus on positioning and identity creation (Bamberg 1997, 2006; Talbot et al. 2008). The main purpose of this study is to highlight the main characteristics created by verbs, adjectives, conjunctions, and pronouns, employed by Malala to create ideological differences between the "perpetrators and victims" (Bamberg, 1997) adopted from Goffman's (2002) classification of "stigmatized" and "non-stigmatized". Goffman's framework suits the data properly for the 
reason that stigma reinforces direct and indirect, economically and socially biased attitudes of non-stigmatized to considerably diminish the credibility and normalcy of the stigmatised people (Jacoby et al. 2005). This study also analyses autobiographical account of Malala Yousafzai, then a teenager Pakistan girl, demonstrating her identity construction as a victimized (Bamberg, 1997) in relation to the perpetrators (Bamberg, 1997), non-stigmatized individual (Goffman, 2002) in relation to stigmatized (Goffman, 2002) in her narrative world. The study employs qualitative analysis in exploring the text for the research questions given as: a). In 'I am Malala,' how does Malala create her own identity? and b). In 'I am Malala,' how does Malala construct the identities of other people in relationship to one another?

\section{Review of literature}

Narratives are rooted in our personal experiences of life and our endeavours to give account of those lived experiences in language (White, 1980). Narrative is the most significant construction which represents human experience in a consequential manner by converting facts into story, (Polkinghorne, 1988), possibly this may be the reason that great deal could be revealed about the narrator in the course of the act of relating the account. The studies have found that relating the accounts of personal experience reveal the raconteur's public character, for instance class (Labov \& Waletzky, 1967), gender (Peterson, 1990) and culture (Basso, 1992; Hester 1996), and the manner in which they exert their influence on speaker's individual distinct voice (Johnstone,1996).

Bamberg's theory of "positioning" (1997, 2005) has come first in winning significance in cogitating self and identity, in which 'positions' are generally observed as embedded in meta narratives nevertheless constructing and preserving some scope for individual exploit. Researchers like Linde (1993), Johnstone (1996), and Schiffrin (1996) insist that the narrative distinctly creates space for the narrator to articulate the personal image in numerous ways. For instance, the act of relating provides an opportunity to the narrator to recreate and talk about past events, and to revise, amend and interpret them. Narrative also generates a possibility for us to hook up the character of our past with our present, and to an extent with the expected future personalities of ours (Ochs, 1994; Polkinghorne, 1988). Thus, through a continual process of reflection and reconsideration, the "reflexive project of the self" (Giddens, 1991, p.52) is maintained as a "(re)construction of personality". As a result, personal experience narratives are far from objective accounts of events (Chafe, 1994; Tannen, 1990). However, in order to be heard "properly," constructing an identity as a character in the narrative universe and inflowing this structure as a claim for the narrator's self requires "extra rhetorical effort" (Bamberg, 1997, p.224). It is this 'additional rhetorical labour,' not the fact that narrators are relaying something more "intimate or personal," that elevates "personal tales" into the domain of linguistic facts (Bamberg, 1997).

Stigma strengthens cultural models and supports and evens out the groups by pushing out undesirable or unwanted characteristics which are considered to cause a risk or threat to the individual or group, drawing a border line in the middle of "them" and "us" (Phelan et al, 2008). This generally assists in confirming the moral authority of the group stigmatizing others, and strengthens their assertion of normalcy (Goffman, 1963). Hence, stigmatizing other persons is a practice of the identity construction. Standard identity does not turn aside the social expectations and is created by ratifying the marginalizing operations and eliminating practices (Nairn et al, 2006). 
Stigmatization results in a general downhill positioning the victims in social hierarchy (Link \& Phelan, 2001). This may reinforce direct or indirect socio-cultural and economic biased actions on the part of non-stigmatized people that considerably decrease the chances of survival of the stigmatized person (Jacoby et al. 2005). The fact that the "non stigmatized" perceive the stigmatised as "not quite human," as a danger, or as filthy and unsafe reinforces this form of rejection operation. As a result, non-stigmatized people are correct in their approach and treatment of stigmatised persons (Jacoby et al. 2005) An unstigmatized person, for example, frequently perceives a stigmatised person as incompetent (Goffman, 1963). The embarrassing emotional responses towards "others" (out-group), such as the aversion reaction that non stigmatized people have when they interact with an unclean, stigmatised person, can exaggerate this embarrassment (Curtis \&Biran, 2001).

I would develop the argument that Malala's account of personal experience as she has related in her autobiography, 'I am Malala', container assertion regarding her perception of identity, and in her efforts to persuade, and put together these assertions as intelligible, she integrates contradictory claims concerning the gender and cultural practices which she assumes may perhaps amount to potential misinterpretation about her.

\section{Research methodology}

The study qualitatively analyzes the first two sections (out of five sections in all) of Malala's personal narrative, I am Malala (2013), as she has provided nearly all references to her familial, religious, and ethnic milieu and experiences in the first two sections. Besides, she has introduced all the key characters in her life story in the selected parts of the autobiography. As Malala discloses in her narrative, she reveals ties and construct identity claims for herself while also drawing on and contesting established gender and race ideologies in her culture (Flannery, 2008). To show the credibility of the events reported in Malala's personal experience narrative, Goffman's (2002) stigmatised and non-stigmatized classifications were used to the stories of unfairness in the narrative.

The intriguing incidents that comprise Malala's account have been reported after the Taliban displayed discrimination against girls' schooling and demonstrated gender prejudice by shutting down girls' schools in her region, the valley Swat. She divides the characters in her story into self and others. Others' disagreeable traits cause a likely risk or threat to her community, or its members as individuals like herself, forming a dividing line between 'them' and 'us' (Phelan et al. 2008). For reinforcing her identity and banishing undesirable others from her community, she employs referring expressions such as adjectives, pronouns, and verbs to characterize the identity of others. She exposes the connection and distance between others and herself to defend the claims about her identity. Stigma is a source of anxiety in the distinct connection between two entities: stigmatized and non-stigmatized individuals, (Goffman, 1963; 2002). The classification of perpetrator and victim (Bamberg, 1997) in the account of Malala, adds credibility in the acts of different characters depicted in the narrative world.

\section{Findings and discussion}

Malala emerges in her story as a character, an author and primary figure, offering explanations that depict her as someone with power however she, simultaneously, attempts to appear compassionate and oppressed. Malala positions herself at multiple levels resulting in diverse degrees of positioning within the narrative world. The characters have been positioned with 
respect to one another primarily through creating distinctions. The conjunctions like while, but, like, however, and though create covert and overt differences between other characters and herself, in the narrated incidents. The identity she constructs for herself is mostly varying and fluid (Musson \& Duberley, 2007). Every so often she appears to be a helpless Pakistani girl (gender identity), occasionally she seems to be a member of a conventional group or community, Pashtuns (her racial identity); at times her words contain conviction and authority as of a hero (identity as an activist for girls' education). In the narrative world, discrimination is embodied in the juxtaposition of the two entities through their actions and roles as victims and perpetrators. Her narrative relates an improbable case where both the perpetrator and the victim (Bamberg, 1997) are members of the same religious, racial, and ethnic group.

\subsection{Malala Yousafzai's Personal Identity Construction}

I am Malala is a sixteen-year-old high school student's account. She describes herself as "contemporary" (37), "born politician" (71), "not like the other girls" (92), and "accustomed to speaking in public" (93). She spent the first fifteen years of her life in the Swat Valley. As she debates gender, religious, racial, and national ideas, she conveys her opinions both subtly and overtly. In the course of the narration of her account, Malala has positioned herself as somebody who got stigmatized and victimized by others because she was enlightened and was struggling to lead her community. She has created manifold subject positions to arbitrate her national, gender, and racial identities. She has structured her positions as remote from Taliban militants who were detrimental to women education, enlightenment, and empowerment.

\subsubsection{National Identity}

Malala seeks to show her love for Pakistan and confronts her detractors, who have stoked tensions by questioning her patriotism and labelling her a Western spy. She defends and justifies her acts in order to demystify and provide meaning to her life events, as well as to protest against those who misunderstand her intentions (Vásquez \& Urza 2009).

Example 1: "Some people say I will never return home, but I believe firmly in my heart that I will. To be torn from the country that you love is not something to wish on anyone" (8).

Example 2: "Instead I am in a country which is five hours behind my beloved homeland Pakistan and my home in the Swat Valley, but my country is centuries behind this one" (8).

She defends her claim that Pakistan is "hundreds of years behind England" as based on fact rather than bias by declaring her love for Pakistan and her desire to remain in the nation. While living abroad, she uses the phrase "my country" to establish her national identity. Malala Yousafzai portrays herself as a smart and liberal activist, yet she strives to keep her national identity in order to be regarded as a patriotic champion for female education in Pakistan.

She frequently identifies herself with her activist father and depicts him as a role model. Nonetheless, unlike her father, she portrays herself as extra-motivated to return to Pakistan:

Example 3: "I know I will go back to Pakistan, but whenever I tell my father I want to go home, he finds excuses" (153). 


\subsubsection{Ethnic Identity}

Despite her affection for the country, Malala gives priority to her ethnicity and race over her patriotism:

Example 1: "I was born a proud daughter of Pakistan, though like all Swatis I thought of myself first as Swati and then Pashtun, before Pakistani" (18).

Example 2: "From an early age I was interested in politics and sat on my father's knee listening to everything he and his friends discussed. But I was more concerned with matters closer to home - our own street to be exact" (47).

Malala establishes her primary identity as a Sawati in order to pave the way for her future efforts in Swat Valley to enhance girls' education (Ex 2). Her stated interest in the issues of her valley above her country, as well as her esteem for ethnic identity, Pashtun/Swati, over national identity, Pakistani, are embedded in her views on Pakistanis $(\mathrm{Ex}, 1)$.

\subsubsection{Gender Identity}

Malala's views on cultural and social problems are frequently revealed through the episodes of discrimination in which she relates events depicting how Pashtun women are mistreated and refused right of participation in different fields of life because of misinterpretation and underrating of their social and religious status by others:

Example 1: "We all played cricket on the street or rooftops together, but I knew as we got older the girls would be expected to stay inside. $W e$ ' $d$ be expected to cook and serve our brothers and fathers. While boys and men could roam freely about town, my mother and I could not go out without a male relative to accompany us, even if it was a five-year-old boy! This was the tradition".

By employing the term "we," she depicts herself as one of the likely victims. Her story represents the conventions of the Sawat Valley. I assume that the word "we" in the preceding line refers to Pashtun women particularly, rather than all Pakistani women. She contrasted a Pashtun woman and a Pashtun man, who would confine women to their homes as soon as they reached the age of adulthood, while they themselves were free to go around.

Malala also puts up various examples of escalating gender discrimination in her community, including the treatment of daughters as personal property:

Example 2: "We have a custom called swara by which a girl can be given to another tribe to resolve a feud. It is officially banned but still continue" (38).

Malala defines herself as a vulnerable part of Pashtun culture as a Pashtun woman by using the word "we" in these situations.

Her father, on the other hand, gave her the freedom to make her own decisions about her schooling, future job, and marriage. Malala, unlike other Pashtun women, was not influenced by the traditional practises that perpetuate gender inequality in Pashtun society: 
Example 3: "Wearing a burqa is like walking inside big fabric shuttlecock with only a grille to see through and on hot days it's like an oven. At least I didn't have to wear one" (38).

She uses the pronoun "I" to distinguish herself from traditional feminine garb, the barqa. She shapes herself into a strong young woman who can choose between ignorance and understanding.

Example 4: "we cast off our head-scarves like winds puffing away clouds to make way for the sun" (8).

She refers to her classmates as "we" because they thought the headscarf was a symbol of captivity. She criticises the burqa and scarf by utilising the imagery of a grille in opposed to autonomy, an oven in opposition to convenience, and clouds in opposition to the sun, all of which represent her identity as a non-conformist to her culture's traditional gender norms. She takes a stand against the Taliban's views on women's clothing, saying:

Example 5: “ $I$ wore more fashionable clothes and didn't cover my face even when $I$ became a teenager" (37).

Example 6: "I was different to the other girls as $I$ didn't cover my face and I used to talk to every teacher and ask questions" (92).

Malala described her clothing as being different from the norm and that of other Pashtun women, who must wear a veil when they reach puberty. By employing the pronoun "I" rather than "we," she frames her own gender identity as a nonconformist to established gender norms and attitudes in her culture. She also portrays herself as a strong and independent woman, in contrast to Pashtun women who suffer as a result of their cultural roots.

\subsubsection{Religious identity}

In her valley, Malala conflates Islamic theory with cultural practices.

Example 1: "The Quran teaches us sabar-patience-but often it feels that we have forgotten the word and think Islam means women sitting at home in purdah or wearing burqas while men do jihad" (49).

Her cultural attitude towards Islam is referenced by her using the term "we." She sees herself as a vulnerable member of the community, a victim, in which women are required to be confined to their homes under the guise of Islam, while men are obliged to fight the holy conflicts. The references to Malala's parents highlight her cultural and political portrayal of herself. They taught her about Islamically sanctioned women's social, economic, and political rights, but such rights were mostly ignored in her community:

Example 2: "We recite in Arabic, and most people don't actually know what the verses mean, but had also started learning them in translation" (70).

She contradicts and separates herself from cultural customs in order to build a religious identity separate from her society's traditional religious rituals. She uses the pronoun "we" to refer to 
other members of her community who also recite in Arabic. She establishes a distinction between her religious practice and that of others who do not understand the interpretation and meanings of the holy book by using the pronoun "I" and the conjunction "but," allowing her to develop her own religious orientation.

\subsection{Malala builds the identities of the other characters in her plot}

\subsubsection{Her mother}

Malala's mother, Tor Pekai, plays a crucial role in her life. Her father did not enforce constraints on her mother's cultural, social and intellectual mobility.

Example 1: "Though my mother cannot read or write, my father shares everything with her, telling her about his day, the good and the bad. She teases him a lot and gives him advice about who she thinks is a genuine friend and who is not, and my father says she is always right. Most Pashtun men never do this, as sharing problems with women is seen as weak" (17).

Example 2: "My mother is very pious and prays five times a day" (17).

Example 3: "My mother comes from a family of strong women as well as influential me" (17).

Tor Pekai, her mother, holds a pivotal position. Malala has described her as a "charitable" (15), "beautiful" (16), "adored by her husband" (16), "generous" (16), "strong woman" (17, 92), "pious" (17), "smart" (17), "practical" (44), "sympathetic" (45), and "powerful" woman (17, 92). (61). Her mother's personality does not fit into the meek role of native Pashtun women, who are always second fiddle to their men. Tor Pekai is a character with a lot of personality. If she is separated into simple levels, kind and generous women are compared to thrifty Pakhtun women, and strong women are compared to domesticated and frightened Pakhtun women who are not admired by their husbands. In comparison to Pashtun women and the cultural context, she stands out. Malala portrays her mother as a unique and aloof figure from the Pashtun women and culture.

\subsubsection{Her Father's Identity}

Malala asserts her father's identity as contradictory to the cultural and racial and norms of the valley. Her father challenged the established racist and prejudiced ideologies in her culture (Flannery 2008) In contrast to the majority of Pashtuns who believe in the Taliban notion due to ignorance, she regards her father as a strong guy who spoke out against them (9):

Example 1: "My mother was worried about me, but the Taliban had never come for a girl, and I was more concerned they would target my father as he was always speaking out against them" (9).

Her father's admiration for his wife (16)as opposed to all other Pashtun men who believed their women to be inferior (13):

Example 2: "My father, Ziauddin, is different frommost Pashtun men" (13). 
Example 3: "My mother is very beautiful, and my father adored her as if she were a fragile China vase, never laying a hand on her, unlike many of our men" (16).

In the face of his beloved's family's opposition, her father showed to be a "stubborn guy" (17) who did not hesitate to proclaim his feelings for his beloved. In contrast to other Pashtuns in the valley, who largely attended religious schools or only high school, he was "well educated" (17). His ferocious speeches earned him the appellation of "Falcon" (20).

Example 4: "My grandfather wrote his speeches, and he almost always came first, gaining a reputation locally as an impressive speaker" (25).

He was dark-skinned (24) in comparison to his tribe's fair-skinned members, but his achievements made him noteworthy. He was a "avid reader" (26), "poet" (26), "talented speaker and debater" (28), "charismatic" (30), "optimistic" (31), "social worker" (32), "nature lover" (38), "mediator of feuds" (41), "charitable" (45), "well-known figure" (45), "fundraiser" (56), "anti feudalism" (56), "courageous" (64), She establishes her father's identification as an individual distinct from the rest of the Pashtun community in order to increase his credibility as a well-known advocate for mass education and environmental protection in the valley. Her father provides the majority of the clear contrasts and scripted conversation in the events described in her tale. Malala attributes to her father the qualities that make him the most significant character in the story.

\subsubsection{Identity of Taliban}

Malala employs references to facial appearance, to create a room to portray the episode of prejudice toward 'others' in her narrative (Flannery, 2008). For example, when she talks about the Taliban and Islamist military ruler Zia ul Haq, both of whom were anti- women's rights, she uses derogatory phrases to demonise them. She introduces the Taliban by addressing their leader as:

Example 1: "The year before I was born, a group called the Taliban led by a one-eyed mullahhad taken over the country and were burning girls' schools" (38).

In Islam, the term "Dajal" means "one-eyed." In Islamic eschatology, it is a wicked character known as "the false messiah" in Arabic.

She depicts the Islamist military dictator Ziaul-Haq as:

Example 2: "He was a scary man with dark panda shadows around his eyes, large teeth that seemed to stand to attention" (21).

Zia ul-Haq is described as a stereotypically awkward-looking, "scary man" with horrible eyes and large teeth, as opposed to a pleasing, pleasant appearance and average tooth size. Malala displays the "discrediting attribute" (Goffman, 2002) of others and their creepy look through the expression of a victim by taking the role of author and primary user of insulting remarks (non-stigmatized individual).

She explains the Taliban's growing impact on her valley as follows: 
Example 3: "Taliban arrived in the night just like vampires. They appeared in groups, armed with knives and Kalashnikovs, and first emerged in Upper Swat, in the hilly areas of Matta” (59).

Vampires are frequently associated with the consumption of blood in Pakistani culture.

Example 4: "These were strange-looking men with long straggly hair and beards" (59).

Despite what she claims earlier in her book, she describes them as strange looking while alluding to their dishevelled appearance: "Taliban were just around the corner and were Pashtuns like us" (38). Nonetheless, Malala portrays the incident as an example of prejudice towards people of her own race (Pashtuns). She brings up the race in an attempt to compare and contrast two people in comparable situations, exposing their roles as victim and offender. She classifies the Taliban as Pashtuns who appear to be aliens, because "they" were the perpetrators of evil while "we," the Pashtuns, were the victims:

Example 5: "We were not fans of the Taliban as we had heard they destroyed girls' schools" (46).

Referring to appearance of Taliban, she states:

Example 6: "They had jogging shoes or cheap plastic sandals on their feet, and sometimes stockings over their heads with holes for their eyes, and they blew their noses dirtily into the ends of their turbans" (59).

Example 7: "They looked so dark and dirty that my father's friend described them as 'people deprived of baths and barbers" (59).

She portrays the Taliban as a community without decency, tidiness, or politeness. She puts the Taliban at a distance by categorising them as aliens, unlike "us," dark as opposed to "light," evil (vampires) as opposed to "purity," and nasty as opposed to "beautiful." She builds the identification of her victim as "we" and refers to the Taliban as "they." She has the authorial power to undermine the Taliban's authority in the eyes of her readers. The choice of terms such as "dark and unclean" and "vampires" reduces the Taliban's identity to that of people with a shameful quality, a stigma (Goffman, 2002), and positions Malala and other Pashtuns in the role of non-stigmatized characters.

Malala makes extensive use of the cultural identities of Taliban members to undermine their rule. For example, she introduces Fazlullah, the leader of Taliban as:

Example 8: "He's actually a high-school dropout whose real name isn't even Fazlullah" (60).

Example 9: "My father became depressed because people had begun to embrace Fazlullah's words and his religious romanticism". "It's ridiculous," my father would say, that "this so-called scholar is spreading ignorance" (60).

Example 10: "Their leader was MaulanaFazlullah, a 28-year-old who used to operate the pulley chair to cross the Swat River and whose right leg dragged because of childhood polio" (59). 
Taliban leader Fazllulah has a dubious past, as he uses a false identity instead of his true name. $\mathrm{He}$ is a phoney scholar, not a genuine one. His educational credentials are insufficient to back up his claim to be a scholar. He prefers ignorance over knowledge and civilisation. He worked as a manual labourer, indicating that he was a member of the impoverished working class with no social position in Pakistani society. Because one of his legs is paralysed, he has less physical strength and stability than someone with a typical body shape. As a plan to undermine radio broadcasting efforts for the application of his philosophy, she refers to the Taliban leader as "Mullah FM" (59, 60, 63, 77, 79, 84) and "Radio Mullah" $(59,61,62,66)$. She portrays the Taliban as being uninformed. She refers to the Taliban's commander as Mulla FM rather than his given name, Fazllulah.

Malala also uses action verbs to represent the Taliban's style of action, reinforcing the distinction between victims and perpetrators.

For example: "Taliban were burning girls' school" (38); "Taliban had even banned women from laughing out loud" (38); "Women were being locked up and beaten just for wearing nail varnish" (38); These action phrases make women victims of the Taliban's anti-women prejudice. Taliban actions have harmed both men and women: "They were forcing men to grow beards and women to wear burqas" (38). Taliban urged people to move from modernism to Talibanism as a way of life.: "They harassed men wearing Western-style shirt' (52) 'banned shaving so there was no work for barbers" (62), "bombed the power station so we had no electricity (75),'they blasted the pipeline so we had no gas either" (75). When verbs like "burn," "force," "ban," "lock-up," "beat," "blow up," "attack," "harass," "set on fire," "smash," "hate," "denounce," "tear into pieces," "bomb," and "blast" are put side by side with basic binaries, the result is positive verbs, indicating the Taliban's distance from positivity and confirmation of their actions as perpetrators of intolerance and brutality.

According to Bamberg (1997:337), analysing positioning in a narrative allows us to notice the different forms of connections that a narrative has with the outside world. A narrative gives the narrator the opportunity to craft comments about the type of person she wants to be identified as by establishing ties with other speech. Malala associates negative statements with the Taliban to complement their stigmatised identity, as the reader can see. To be controversial, the statement must be uttered by a victim who has a "non-stigmatized" identity, because only then can the prejudicial thought be justified. As a result, Malala has demonstrated disrespect and disregard for persons who have a stigmatised identity (Goffman, 2002). Malala and other Pashtun people in her history have taken a stand that is not just one of solidarity and empathy for her race, but also one of a collective non-stigmatized background as a victim.

\section{Conclusion}

This work adds to the field of identity and race research by evaluating an autobiography and focusing on positioning and identity creation using linguistic elements. The study shows how Goffman's (2002) categories of "non-stigmatized" and "stigmatised" (adapted as victim and perpetrator by Bamberg 1997) apply to Malala's story of prejudice. It discusses the formation and projection of identity in a personal account of racial and gender discrimination, as well as the significance of language in communicating theoretical unfairness by a victim of gender discrimination, as well as an individual's sense of self. Malala describes everyday life experiences within her narrative by placing people in relation to one another. Throughout her narrative, Taliban and culture are positioned as discriminatory and perpetrators of evil. As 
proposed by Goffman, at whatever time a person's stigmatized trait is exposed, "[h]e is reduced in our minds from a whole and usual person to a tainted, discounted one" (1963, p.3).

Malala assigns positions to herself based on her broad beliefs about race, culture, and gender through the narration of her actual experiences. She uses specific linguistic tactics to establish clear places for herself and other characters. She is not the only important character in the novel, nor does she remain the same throughout, but she takes on the roles of victim, figure, and author, and portrays her characters in parallel roles. She positioned herself as logical and moderate to substantiate that her opinions and attitudes towards other characters in the narrative world were commonly not biased. These multiple positions bring about particular identities and establish significant relationships. In addition, the events shared by Malala with the readers also refer to the beliefs and grounds of discrimination and prejudice in the Pashtun community, for example, by signifying that in Pashtun culture discrimination is predictable towards women; Malala depicts herself as an unlikely example of sensible, intelligent and independent young girl keen to penetrate into mainstream of life by defying the prejudice against women.

Future research could look into Malala's and other young authors' perspectives toward their origin, culture, and gender. Conducting a comparison research of Malala Yousafzai's blog, "The Diary of a Pakistani Schoolgirl," published by BBC in 2009 on its website to the life story of an internationally known campaigner will be a beneficial study, I am Malala, published in 2013. It will be helpful in tracing her strategies of positioning and identity construction in relation to other individuals in her narrative during four years time period. It will in addition enhance the abilities of readers to relate the linguistic strategies and experiences of Malala to their daily life ideologies and experiences of religion, race, and gender in their society.

\section{References}

Arnoldy, B. (2012), The Malala Moment: 6 Pakistani Views on the Girl Shot by the Taliban, The Christian Science Monitor 15. http://www.csmonitor.com/ World/Asia-SouthCentral/2012/1015/The-Malala-moment-6-Pakistani-views on- the-girl-shot-by-theTaliban/I-want-my-daughter-to-love-my-faith-so-she-will-not-visit-Pakistan

Ashish T, E., \& Narain S. R. (2015). Framing of Malala Yousafzai: a comparative analysis of news coverage in Western and Pakistani mainstream English print and alternative media. Media Asia, 42(3-4), 225-241.

Associated Press. (2015, November 5). "Malala Yousafzai tells Emma Watson: I'm a feminist thanks to you." The Guardian. Retrieved fromhttps://www.theguardian.com/world/2015/nov/05/malala-yousafzai-tellsemmawatson-im-a-feminist-thanks-to-you

Aziz, U., Buncombe. A. (2013), Inspiration or Danger? Private Schools in Pakistan Ban Malala Yousafzai's Book, The Independent 10/11. $\underline{\text { http://www. }}$ independent.co.uk/news/world/asia/inspiration-or-danger-private-schoolsinpakistan-ban-malala-yousafzais-book-8930925.html> (09/2014).

Baig, A. (2013). Malala Yousafzai and the White Saviour Complex. Huffington Post, Retrieved May 30, 2015 from https://www.huffingtonpost.co.uk/assed-baig/malala-yousafzaiwhite saviourb3592165.html

Bamberg, M. (2003). We are young, responsible and male: Form and function of slut-bashing in the identity constructions in 15-year-old males. Human Development, 47, 331-353. 
Bamberg, M. (2004). Talk, Small Stories, and Adolescent Identities. Human Development 47, $366-369$.

Bamberg, M. (2005). Narrative discourse and identities. Narratology beyond literary criticism: Mediality Disciplinarity. Berlin: Walter de Gruyter, 213-237.

Bamberg, M. G. (1997). Positioning between structure and performance. Journal of narrative and life history, 7(4), 335-342.

Bamberg, M. (2004). Talk, Small Stories, and Adolescent Identities. Human Development47, $366-369$.

Bamberg, M. (2006). Stories: Big or small: Why do we care? Narrative inquiry, 16(1), 139147.

Basso, E. (1992). Contextualization in Kalapalo Narratives, In A. Duranti, A. \& Goodwin, C. (Ed) Rethinking Context. Cambridge: Cambridge University Press.

Chafe, W. (1994). Discourse, consciousness, and time: The flow and displacement of conscious experience in speaking and writing. University of Chicago Press.

Curtis, V. \&Biran, A. (2001). Dirt, disgust and disease: Is hygiene in our genes? Perspectives in biology and medicine, 44 (1), 17-31.

Flannery, M. S. (2008). "She discriminated against her own race": Voicing and identity in a story of discrimination. Narrative Inquiry, 18(1), 111-130.

García, A. B. M. (2020). Women activists' strategies of online self-presentation. AI \& Society: Journal of Knowledge, Culture and Communication. Special Issue on Iteration as Persuasion in a Digital World, 1-12.

Giddens, A. (1991) Modernity and Self-identity: Self and Society in the Late Modern Age. Stanford University Press.

Goffman, E. (2002). The presentation of self in everyday life. Garden City, NY.

Goffman, E. (1963). Stigma: Notes on the Management of Spoiled Identity. Prentice-Hall.

Hester, E.J. (1996) 'Narratives of Young African American Children', In Kamhhi, A. G.,

Pollock, K. E., \& Harris, J. L. (Ed) Communication Development and Disorders in African American Children: Research Assessment and Intervention. Paul H. Brooks.

Jacoby, A., Snape, D., \& Baker, G. A. (2005). Epilepsy and social identity: the stigma of a chronic neurological disorder. The Lancet Neurology, 4(3), 171-178.

Johnstone, B. (1996) The Linguistic Individual. Oxford: Oxford University Press.

Agency (pp. 157-171). Springer, Cham.

Labov, W. \& Waletzky, J. (1967). Narrative analysis: Oral versions of personal experience. In Helm, J. (Ed.) Essays on the Verbal and Visual Arts. American Ethnological Society.

Linde, C. (1993). Life Stories. Oxford: Oxford University Press.

Link, B. G., \& Phelan, J. C. (2001). Conceptualizing stigma. Annual Review of Sociology, 363385.

Malala Yousafzai: Portrait of the girl blogger, $B B C$ News, October 10, 2012, http://www.bbc.co.uk/news/magazine-19899540, accessed on August 2014.

Musson, G., \& Duberley, J. (2007). Change, change or be exchanged: The discourse of participation and the manufacture of Identity. Journal of Management Studies, 44(1), 143-164.

Nairn, K., Higgins, J., Thompson, B., Anderson, M., \& Fu, N. (2006). It's Just Like the Teenage Stereotype, You Go Out and Drink and Stuff: Hearing from Young People who Don't Drink. Journal of youth studies, 9(3), 287-304.

Ochs, E. \& Capps, L. (1996). Narrating the Self, Annual Review of Anthropology 25: 19-43

Ochs, E. (1994). Stories that Step into the Future, In Biber, D. \& Finegan, E. (Ed) Sociolinguistic Perspectives on Register. Oxford: Oxford University Press. 
Peterson, L. (1990) Female Auto biographer, Narrative Duplicity, Studies in Literary Imagination 23, 165-76.

Phelan, J. C., Link, B. G., \&Dovidio, J. F. (2008). Stigma and prejudice: One animal or two? Social Science \& Medicine, 67(3), 358-367.

Polkinghorne, D. (1988) Narrative Knowing and the Human Sciences. State University

Schiffrin, D. (1996). Narrative as Self Portrait: Sociolinguistic Construction of Identity, Language in Society 25: 167-203.

Siddiqui, T. (2013), MalalaYousafzai: Why the Global Hero is Scorned in Pakistan, The CS Monitor. http://www.csmonitor.com/World/Asia-South-Central/2013/1008/MalalaYousafzai-Why-the-global-hero-isscorned- in-Pakistan-video

Talbot, M. (2008). 20 Gender Stereotypes: Reproduction and Challenge. The handbook of language and gender, (25), 468.

Tannen, D. (1990). Gender differences in topical coherence: Creating involvement in best friends' talk. Discourse Processes, 13(1), 73-90.

Vásquez, C., \&Urzúa, A. (2009). Reported speech and reported mental states in mentoring meetings: Exploring novice teacher identities. Research on Language and Social Interaction, 42(1), 1-19.

Waraich, O. (2013), Pakistan's Malala Problem: Teen Activist's Global Celebrity Not Matched at Home, Time, Retrieved September 15, 2013 from http://world.time.com/2013/07/15/ pakistans-malala-problem-teen-activists-globalcelebrity-not-matched-at home

White, H. (1980). The Value of Narrativity in the Representation of Reality, Critical Inquiry, 7(1), 5-27.

Whitlock, G. (2010). Soft Weapons: Autobiography in transit. University of Chicago Press.

Yousafzai, M. (2013). A World at School. Malala Yousafzaia's speech at the United Nations. https://www.theguardian.com/ commentisfree/2013/Jul/12/malala-yousafzai-unitednations-education-speech-text

Yousafzai, M., \& Lamb, C. (2013). I am Malala: The Story of the Girl Who Stood Up for Education and was Shot by the Taliban. Hachette UK.

Zahra-M. (2013), Malala, Pakistani Teen Who Survived Taliban Attack, Resented in Hometown", The Huffington Post. http://www. huffingtonpost.com /2013/10/11/ $\underline{\text { malala-pakistan_n_4083188.html }}$ 